\title{
RESPONS PERTUMBUHAN DAN HASIL TANAMAN SELEDRI (APIUM GRAVEOLENS L.) TERHADAP MEDIA TANAM DAN KONSENTRASI LARUTAN NUTRISI YANG BERBEDA PADA WICK SYSTEM
}

\section{(Growth Response and Yield of Celery Plant (Apium graveolens L.) to Planting Media and Concentration of Different Nutrient Solutions in Wick System)}

\author{
Maria Ulfa $^{1)}$, Hadi Pranoto ${ }^{2)}$, Susylowati ${ }^{2}$ \\ ${ }^{1)}$ Alumni Jurusan Agroekoteknologi Faperta Universitas Mulawarman \\ ${ }^{2)}$ Fakultas Pertanian,Universitas Mulawarman, Samarinda, \\ Jalan Pasir Balengkong,Gunung Kelua,KalimantanTimur \\ Penulis koresponden: susy_rusdi2 @yahoo.com
}

Article Submitted: 20-02-2021

Article Accepted: 24-05-2021

\begin{abstract}
This research aims to find out 1) the interaction between the medium of planting and the concentration of nutrient solutions to the growth and yield of celery plants hydroponically. 2) types of planting media that can give different influences on the growth and yield of celery plants, and 3) concentration of nutrient solution that provides the best growth and yield of celery plants in different planting media.The research was conducted from December 2019 to February 2020 at the Integrated Laboratory of the Faculty of Agriculture of Mulawarman University, Samarinda. The research used factorial exsperiment $3 \times 4$ on Randomized Completely Block Design (RCBD), replicated three times with each treatment consisting of three plants. The first factor is the planting medium consisting of rockwool, charcoal husk, and combination of charcoal husk + tea amps. The second factor is the concentration of $\mathrm{AB}$ Mix nutrient solution consists of 500, 1,000, 1,500, and 2,000 ppm. The data was analyzed with test $\mathrm{F}$ and continued Least Significant Difference (LSD) test with a level of 5\%. The results showed that there is an interaction between planting media and concentration of nutrient solution in the growth and yield of celery plants. The interaction between the combination of charcoal planting media + tea pulp and concentration of $1,500 \mathrm{ppm}$ is not real with the interaction of rockwool planting media and concentration of $1,500 \mathrm{ppm}$. From various types of planting media used, charcoal husk planting media provides the best influence on the growth and yield of celery plants. Based on polynomial orthogonal test the concentration of nutrient solution with an optimum point of 1,460.84 ppm affects the growth and yield of celery plants with a maximum dry weight of $2.14 \mathrm{~g}$.
\end{abstract}

Keywords: Celery, Hydroponics, Planting Media, Nutrition AB Mix.

\section{PENDAHULUAN}

Indonesia merupakan negara agraris yang mayoritas penduduknya bermata pencaharian sebagai petani. Tanah di Indonesia memiliki kandungan unsur hara yang cukup baik sehingga dapat membantu proses pertumbuhan tanaman. Produk yang menjadi unggulan di Indonesia adalah tanaman sayuran. Terdapat banyak jenis tanaman sayuran yang dibudidayakan petani, salah satu diantaranya yaitu tanaman seledri.

Tanaman seledri merupakan tanaman sayuran yang sudah lama dikenal di Indonesia. Tanaman seledri bersifat aditif dalam bahan makanan sehingga dipergunakan dengan jumlah sedikit tetapi 
penting dalam beberapa menu masakan. Tangkai dan daun seledri dapat digunakan sebagai campuran makanan seperti soto, sup dan makanan berkuah lainnya. Seledri didalam dunia kesehatan berguna untuk mengobati penyakit pada tubuh, yaitu rematik, darah tinggi, dan susah tidur.

Pemerintah kini mulai menerapkan Gerakan Masyarakat Hidup Sehat (GERMAS). GERMAS berfokus pada tiga aktivitas utama, salah satunya yaitu mengkonsumsi sayuran dan buah-buahan setiap hari. Adanya GERMAS yang ditetapkan, kini masyarakat membutuhkan sayuran khususnya seledri dengan kualitas dan kuantitas yang tinggi. Hal ini dapat dilihat ketika hendak membeli sayuran dipasar masyarakat sudah memperhatikan tingkat keamanan dan kebersihannya. Selain itu, masyarakat juga menginginkan budidaya seledri yang tentunya mudah dan ramah lingkungan. Untuk mendapatkan sayuran yang memiliki kualitas dan kuantitas yang bersih, sehat dengan kandungan nutrisi yang cukup untuk kesehatan tubuh dan tentunya ramah lingkungan dapat dilakukan dengan metode hidroponik.

Hidroponik adalah sistem bercocok tanam tanpa tanah sebagai media tanamnya. Teknik penanaman secara hidroponik terdiri dari beberapa macam salah satu diantaranya adalah wick system atau sistem sumbu. Sistem sumbu digunakan dalam budidaya tanaman hidroponik karena sistem sumbu merupakan metode hidroponik yang paling sederhana dan sangat cocok bagi pemula hidroponik. Keberhasilan budidaya hidroponik sistem sumbu dipengaruhi oleh kain sumbu, media tanam dan larutan nutrisi. Sumbu memiliki peranan yang penting yaitu sebagai penghubung antara nutrisi dan perakaran pada bagian media tanam sehingga penyerapan unsur hara lebih terjangkau dan terjadi secara terus menerus (Mas'ud, 2007).

Media tanam merupakan bahan yang bersentuhan langsung dengan akar tanaman. Media tanam dalam sistem hidroponik berperan sebagai pegangan akar dan air agar tanaman dapat tumbuh tegak. Syarat-syarat media tanam yang dapat digunakan pada budidaya hidroponik yaitu bersifat porous, ringan, mampu menerap dan meneruskan larutan nutrisi ke tanaman.

Rockwool merupakan media tanam yang sangat familiar dan yang paling umum digunakan para petani dalam budidaya tanaman hidroponik. Media arang sekam merupakan media yang terbuat dari hasil pembakaran sekam padi. Media ini memiliki daya serap air yang sedang, tetapi cepat menguap. Arang sekam memiliki tekstur yang kasar, memiliki banyak pori dan mampu menghilangkan pengaruh penyakit, khususnya bakteri. Arang sekam dalam sistem hidroponik dapat digunakan pada persemaian atau pada masa pertumbuhan (Perwitasari, 2012).

Masyarakat Indonesia tidak asing lagi dengan minum teh, akan tetapi banyak dari mereka yang kurang mengetahui manfaat ampas teh, karena setelah diseduh ampas teh biasanya langsung dibuang ke tempat sampah. Ampas teh dapat dimanfaatkan dalam dunia pertanian sebagai pupuk organik karena adanya kandungan nitrogen yang mudah diserap oleh tanaman. Ampas teh juga mengandung berbagai macam mineral untuk tanaman dan menjadi penyedia hara melalui proses dekomposisi (Rahayu, 2014).

Faktor lain yang berperan penting dalam keberhasilan sistem hidroponik selain media tanam yaitu larutan nutrisi. Larutan nutrisi merupakan campuran nutrisi yang dilarutkan ke dalam air dan digunakan untuk pemupukan pada tanaman hidroponik. Larutan nutrisi diformulasikan sesuai dengan kebutuhan tanaman serta mengandung unsur hara makro dan mikro yang membantu dalam proses pertumbuhan serta perkembangan tanaman. Keuntungan penggunaan larutan nutrisi dalam hidroponik sistem sumbu yaitu lebih mudah dalam pengendalian nutrisi sehingga pemberian 
nutrisi lebih efisien dan relatif (Nurmayanti, 2008).

\section{METODE PENELITIAN}

Penelitian dilaksanakan pada Bulan Desember 2019 sampai Februari 2020, di Laboratorium Terpadu Fakultas Pertanian Universitas Mulawarman, Samarinda.

Bahan yang digunakan dalam penelitian ini adalah benih tanaman seledri Aroma SD 1011, rockwool, ampas teh, arang sekam, nutrisi AB Mix, air, dan tanah. Sedangkan alat yang digunakan pada penelitian ini yaitu alat tulis, penggaris, alat dokumentasi, botol plastik volume 1,5 L, kain flannel, paku, cutter, nampan plastik, hand spayer, gelas ukur, kertas label, pengaduk, ember, timbangan analitik, bambu, tali, paranet, dan TDS meter.

Penelitian ini merupakan percobaan faktorial $3 \times 4$ yang disusun dalam Rancangan Acak Kelompok (RAK) dengan 3 (tiga) ulangan dan setiap perlakuan dan ulangan terdiri dari 3 (tiga) tanaman.Faktor pertama adalah media tanam, yaitu: $\mathrm{m}_{0}=$ rockwool (kontrol), $\mathrm{m}_{1}=$ arang sekam, $\mathrm{m}_{2}=$ arang sekam + ampas teh (1:1), sedangkan faktor kedua adalah konsentrasi dari larutan nutrisi $\mathrm{AB}$ Mix, yaitu: $\mathrm{k}_{1}=500 \mathrm{ppm}, \mathrm{k}_{2}=$ $1.000 \mathrm{ppm}, \mathrm{k}_{3}=1.500 \mathrm{ppm}$, dan $\mathrm{k}_{4}=2.000$ ppm. Data yang diperoleh dianalisis dengan sidik ragam, untuk membandingkan dua rata-rata perlakuan akan dilanjutkan dengan Uji Beda Nyata Terkecil (BNT) pada taraf $5 \%$.

Pelaksanaan penelitian diawali dengan persemaian yang dilakukan pada kotak persemaian (nampan) berukuran $40 \times 30 \mathrm{~cm}$. Kotak persemaian diisi campuran tanah dan arang sekam dengan perbandingan $1: 1$. Benih ditabur secara merata di atas permukaan tanah, setelah itu ditutup tipis dengan tanah. Wadah tanam yang digunakan terdiri atas dua pot, pot pertama berisi media tanam sedangkan pot kedua berisi air atau nutrisi untuk tanaman. Pot yang digunakan berasal dari botol plastik bekas berukuran 1,5 L. Botol dibelah menjadi dua bagian (bagian atas dan bagian bawah). Pada bagian atas diberi lubang untuk memasukkan kain flannel sebagai sumbu.

Tahap pembuatan larutan nutrisi $\mathrm{AB}$ Mix diawali dengan menyiapkan nutrisi A dan B. Untuk membuat larutan nutrisi $A B$ Mix sesuai dengan konsentrasi yang dibutuhkan yaitu dengan cara mencampurkan masing-masing nutrisi A dan nutrisi B. Konsentrasi larutan nutrisi 500 ppm yaitu 17,5 mL, konsentrasi 1.000 ppm yaitu $35 \mathrm{~mL}$, konsentrasi $1.500 \mathrm{ppm}$ yaitu $52,5 \mathrm{~mL}$, dan konsentrasi 2.000 yaitu $70 \mathrm{~mL}$. Media tanam yang digunakan yaitu rockwool, arang sekam, dan ampas teh. Rockwool dan arang sekam didapatkan dari membeli di toko pertanian. Ampas teh sebelum digunakan dikeringanginkan selama 2-3 hari sampai kondisinya lembap. Media tanam kombinasi dibuat dengan cara mencampurkan arang sekam dan ampas teh dengan perbandingan $1: 1$.

Penanaman dilakukan setelah bibit seledri memiliki 3-4 helai daun atau pada umur 30 hari setelah semai. Setelah dilakukan pindah tanam, tanaman harus selalu dipantau secara rutin. Pemeliharaan dalam penanaman hidroponik yaitu pengecekan konsentrasi larutan nutrisi dan pengendalian OPT. Tanaman seledri dipanen pada umur 50 hari setelah pindah tanam (HSPT).

Variabel yang diamati pada penelitian ini yaitu: pertambahan tinggi tanaman, pertambahan jumlah batang, pertambahan jumlah daun, jumlah anakan, berat segar per tanaman dan berat kering per tanaman. Pengamatan dilakukan pada umur 7, 14, 21, 28 dan 35 HSPT.

\section{HASIL DAN PEMBAHASAN}

Interaksi antara Media Tanam dan Konsentrasi Larutan Nutrisi Terhadap Pertumbuhan dan Hasil Tanaman Seledri (Apium graveolens L.)

Hasil sidik ragam interaksi antara media tanam dan konsentrasi larutan nutrisi menunjukkan pengaruh tidak nyata pada 
variabel pertambahan tinggi tanaman (7 sampai 28 HSPT), pertambahan jumlah batang (7 sampai 35 HSPT), pertambahan jumlah daun (7, 28 dan 35 HSPT), dan jumlah anakan. Hal ini diduga karena antara media tanam dan konsentrasi larutan nutrisi tidak terdapat hubungan yang saling mempengaruhi. Setiap taraf dari kedua faktor berpengaruh secara terpisah dalam meningkatkan pertumbuhan dari hasil tanaman (Sari, 2016). Selain itu, curah hujan yang tinggi selama penelitian mempengaruhi pertumbuhan dari tanaman seledri. Curah hujan yang tinggi mengakibatkan penampung larutan nutrisi tercampur air hujan, hal ini menyebabkan terjadi perubahan konsentrasi larutan nutrisi menjadi lebih encer. Konsentrasi yang lebih encer mengakibatkan ketersediaan unsur hara akan menurun sehingga tanaman tidak memberikan pertumbuhan secara maksimal.

Tabel 1. Interaksi Media Tanam dan Konsentrasi Larutan Nutrisi Terhadap Pertumbuhan dan Hasil Tanaman Seledri

\begin{tabular}{|c|c|c|c|c|c|c|c|c|c|c|c|c|c|c|c|c|c|c|}
\hline \multirow{2}{*}{$\begin{array}{c}\text { Media } \\
\text { tanam } \\
(\mathrm{m})\end{array}$} & \multicolumn{5}{|c|}{ Pertambahan tinggi tanaman $(\mathrm{cm})$} & \multicolumn{5}{|c|}{ Pertambahan jumlah batang (helai) } & \multicolumn{5}{|c|}{ Pertambahan jumlah daun (helai) } & \multirow[b]{2}{*}{$\begin{array}{l}\text { J. anakan } \\
\text { (rumpun) }\end{array}$} & \multirow{2}{*}{$\begin{array}{l}\text { B. B. per } \\
\text { tanaman } \\
\text { (g) }\end{array}$} & \multirow{2}{*}{$\begin{array}{l}\text { B. K. per } \\
\text { tanaman } \\
\text { (g) }\end{array}$} \\
\hline & $\begin{array}{c}7 \\
\text { HSPT }\end{array}$ & $\begin{array}{c}14 \\
\text { HSPT }\end{array}$ & $\begin{array}{c}21 \\
\text { HSPT }\end{array}$ & $\begin{array}{c}28 \\
\text { HSPT }\end{array}$ & 35 HSPT & $\begin{array}{c}7 \\
\text { HSPT }\end{array}$ & $\begin{array}{c}14 \\
\text { HSPT }\end{array}$ & $\begin{array}{c}21 \\
\text { HSPT }\end{array}$ & $\begin{array}{c}28 \\
\text { HSPT }\end{array}$ & $\begin{array}{c}35 \\
\text { HSPT }\end{array}$ & $\begin{array}{c}7 \\
\text { HSPT }\end{array}$ & 14 HSPT & 21 HSPT & $\begin{array}{c}28 \\
\text { HSPT }\end{array}$ & $\begin{array}{c}35 \\
\text { HSPT }\end{array}$ & & & \\
\hline m0k1 & 0,22 & 0,42 & 6,56 & 10,35 & $13,97 \mathrm{Ab}$ & 0,67 & 1,22 & 3,56 & 5,61 & 7,72 & 2,56 & 4,56Aba & $10,78 \mathrm{Aa}$ & 18,83 & 26,89 & 1,33 & $12,45 \mathrm{Aa}$ & $1,73 \mathrm{Aa}$ \\
\hline $\mathrm{m} 1 \mathrm{k} 1$ & 0,28 & 1,78 & 6,53 & 9,92 & $10,99 \mathrm{Aab}$ & 0,66 & 2,00 & 3,44 & 4,00 & 4,11 & 2,44 & $5,78 \mathrm{Aa}$ & $12,78 \mathrm{Aa}$ & 15,39 & 21,56 & 0,00 & $11,48 \mathrm{Aba}$ & 1,60Aba \\
\hline $\mathrm{m} 2 \mathrm{k} 1$ & 0,78 & 0,63 & 2,53 & 7,13 & $9,93 \mathrm{Aa}$ & 0,67 & 1,22 & 2,55 & 3,55 & 4,00 & 2,33 & 4,56Aba & $7,89 \mathrm{Aa}$ & 10,78 & 17,22 & 0,00 & $8,70 \mathrm{Aa}$ & $0.98 \mathrm{Aa}$ \\
\hline $\mathrm{m} 0 \mathrm{k} 2$ & 0,88 & 3,56 & 8,94 & 10,09 & $18,39 \mathrm{Bb}$ & 0,67 & 1,22 & 4,00 & 7,33 & 10,00 & 1,89 & $3,67 \mathrm{Aa}$ & $10,67 \mathrm{Aa}$ & 23,55 & 34,11 & 2,67 & $21,91 \mathrm{Bb}$ & $2,30 \mathrm{Bb}$ \\
\hline $\mathrm{m} 1 \mathrm{k} 2$ & 0,96 & 3,84 & 8,81 & 11,73 & $14,49 \mathrm{Ba}$ & 0,67 & 2,22 & 5,33 & 7,22 & 7,00 & 1,22 & $8,22 \mathrm{Ab}$ & $16,67 \mathrm{Aa}$ & 21,56 & 26,45 & 2,67 & $12,42 \mathrm{Aba}$ & 1,55Aba \\
\hline $\mathrm{m} 2 \mathrm{k} 2$ & 0,24 & 0,32 & 2,78 & 9,51 & $11,52 \mathrm{Aa}$ & 0,52 & 1,11 & 3,00 & 5,33 & 6,78 & 1,78 & $3,74 \mathrm{Aa}$ & $8,34 \mathrm{Aa}$ & 16,11 & 23,67 & 1,00 & $12,96 \mathrm{Aa}$ & $1,43 \mathrm{Aa}$ \\
\hline $\mathrm{m} 0 \mathrm{k} 3$ & 0,73 & 5,01 & 11,00 & 16,3 & $19,06 \mathrm{Bb}$ & 0,89 & 3,45 & 8,00 & 10,33 & 12,33 & 3,00 & $10,78 \mathrm{Cb}$ & $28,78 \mathrm{Bb}$ & 37,67 & 47,00 & 5,00 & $21,21 \mathrm{Ba}$ & $2,35 \mathrm{Ba}$ \\
\hline $\mathrm{m} 1 \mathrm{k} 3$ & 1,10 & 3,10 & 8,14 & 12,24 & $17,20 \mathrm{Ba}$ & 0,44 & 2,00 & 3,33 & 6,44 & 6,89 & 1,55 & $6,11 \mathrm{Aa}$ & $11,11 \mathrm{Aa}$ & 20,45 & 27,89 & 2,67 & $17,93 \mathrm{Ba}$ & $2,11 \mathrm{Ba}$ \\
\hline $\mathrm{m} 2 \mathrm{k} 3$ & 1,44 & 1,83 & 7,02 & 13,63 & $18,00 \mathrm{Bb}$ & 0,56 & 1,34 & 4,11 & 5,89 & 7,11 & 2,44 & 7,33Ва & $12,11 \mathrm{Aa}$ & 22,22 & 31,22 & 2,00 & $22,50 \mathrm{Ba}$ & $2,58 \mathrm{Ba}$ \\
\hline $\mathrm{m} 0 \mathrm{k} 4$ & 0,33 & 2,13 & 8,21 & 16,58 & $18,18 \mathrm{Bb}$ & 0,56 & 1,78 & 5,44 & 7,78 & 8,78 & 2,22 & $7,11 \mathrm{Bb}$ & $17,33 \mathrm{Aa}$ & 28,56 & 38,67 & 3,33 & $19,51 \mathrm{Abb}$ & $2,20 \mathrm{Bb}$ \\
\hline $\mathrm{m} 1 \mathrm{k} 4$ & 0,81 & 2,78 & 6,63 & 9,52 & $10,69 \mathrm{Aa}$ & 0,78 & 1,89 & 3,56 & 5,22 & 4,22 & 3,11 & 5,56Aab & $10,89 \mathrm{Aa}$ & 13,66 & 16,33 & 1,67 & $7,58 \mathrm{Aa}$ & $1,01 \mathrm{Aa}$ \\
\hline $\mathrm{m} 2 \mathrm{k} 4$ & 0,29 & 0,48 & 4,97 & 11,87 & $16,41 \mathrm{Bb}$ & 0,63 & 1,22 & 3,34 & 6,00 & 7,78 & 1,55 & $3,22 \mathrm{Aa}$ & $11,45 \mathrm{Aa}$ & 20,00 & 28,67 & 2,33 & $20,36 \mathrm{Bb}$ & $2,28 \mathrm{Bb}$ \\
\hline BNT 5\% & - & - & - & - & 3,31 & - & - & - & - & - & - & 3,33 & 9,59 & - & - & - & 7,06 & 0,78 \\
\hline
\end{tabular}

Hasil sidik ragam pada pertumbuhan dan hasil tanaman seledri menunjukkan bahwa interaksi antara media tanam dan konsentrasi larutan nutrisi berpengaruh nyata terhadap variabel pertambahan tinggi tanaman 35 HSPT, jumlah daun 14 HSPT dan 21 HSPT, berat segar dan berat kering per tanaman. [10] media tanam dan konsentrasi larutan nutrisi yang berbeda memberikan hasil yang berbeda terhadap pertumbuhan dan hasil tanaman. Media tanam berfungsi sebagai tempat bertumpu tanaman dan tempat akar untuk beraktivitas dalam menyerap nutrisi serta berkembang. Perakaran pada tanaman akan berkembang dengan baik apabila didukung oleh unsur hara, air dan udara yang cukup dari media tanam (Perwitasari, 2012). Jika penggunaan media tanam tidak sesuai dengan yang dikehendaki tanaman maka perakaran pun akan sulit beraktivitas dalam menyerap nutrisi. Kemampuan media tanam dalam menyimpan larutan nutrisi akan berpengaruh pada ketersediaan unsur hara yang dibutuhkan oleh tanaman. Tanaman akan tumbuh subur apabila ketersediaan unsur hara, baik unsur hara makro maupun mikro yang dibutuhkan oleh tanaman tersedia dengan cukup (Sunarjono, 2003)..

Tanaman dapat memberikan hasil yang optimal jika mendapatkan nutrisi yang cukup untuk mendukung proses pertumbuhan dan perkembangan tanaman, karena kebutuhan nutrisi setiap jenis tanaman berbeda-beda (Tripana, 2018). Hal ini berarti penggunaan media tanam dan konsentrasi larutan nutrisi yang tepat akan memberikan hasil yang optimal terhadap pertumbuhan dan hasil tanaman.

\section{Pengaruh Media Tanam terhadap Pertumbuhan dan Hasil Tanaman Seledri (Apium graveolens L.)}

Hasil sidik ragam menunjukkan bahwa penggunaan media tanam berpengaruh tidak 
nyata pada variabel pertambahan tinggi tanaman dan jumlah batang pada umur 7 HSPT, serta pertambahan jumlah daun 7 dan 14 HSPT. Umur tanaman 7 HSPT, media tanam tidak memberikan pengaruh terhadap pertambahan tinggi tanaman, jumlah batang, dan jumlah daun karena tanaman seledri yang baru dipindahkan dari persemaian perakarannya belum beradaptasi dan berkembang pada media tanam yang baru. Media tanam merupakan salah satu faktor yang mempengaruhi perkembangan dari akar. Dinyatakan oleh Grewal (1998) bahwa tanaman yang dipindahkan dari persemaian ke media tanam yang baru memerlukan waktu untuk beradaptasi antara akar dan media tanam dalam menyerap nutrisi.

Tabel 2. Pengaruh Media Tanam terhadap Pertumbuhan dan Hasil Tanaman Seledri

\begin{tabular}{|c|c|c|c|c|c|c|c|c|c|c|c|c|c|c|c|c|c|c|}
\hline \multirow{2}{*}{$\begin{array}{c}\text { Media } \\
\text { tanam } \\
(\mathrm{m})\end{array}$} & \multicolumn{5}{|c|}{ Pertambahan tinggi tanaman $(\mathrm{cm})$} & \multicolumn{5}{|c|}{ Pertambahan jumlah batang (helai) } & \multicolumn{5}{|c|}{ Pertambahan jumlah daun (helai) } & \multirow[b]{2}{*}{$\begin{array}{l}\text { J. anakan } \\
\text { (rumpun) }\end{array}$} & \multirow{2}{*}{$\begin{array}{c}\text { B. B. per } \\
\text { tanaman } \\
\text { (g) }\end{array}$} & \multirow{2}{*}{$\begin{array}{c}\text { B. K. per } \\
\text { tanaman } \\
\text { (g) }\end{array}$} \\
\hline & $\begin{array}{c}7 \\
\text { HSPT }\end{array}$ & $\begin{array}{c}14 \\
\text { HSPT }\end{array}$ & $\begin{array}{c}21 \\
\text { HSPT }\end{array}$ & $\begin{array}{c}28 \\
\text { HSPT }\end{array}$ & 35 HSPT & $\begin{array}{c}7 \\
\text { HSPT }\end{array}$ & $\begin{array}{c}14 \\
\text { HSPT }\end{array}$ & $\begin{array}{c}21 \\
\text { HSPT }\end{array}$ & $\begin{array}{c}28 \\
\text { HSPT }\end{array}$ & $\begin{array}{c}35 \\
\text { HSPT }\end{array}$ & $\begin{array}{c}7 \\
\text { HSPT }\end{array}$ & $\begin{array}{l}14 \\
\text { HSPT }\end{array}$ & $\begin{array}{l}21 \\
\text { HSPT }\end{array}$ & $\begin{array}{c}28 \\
\text { HSPT }\end{array}$ & $\begin{array}{c}35 \\
\text { HSPT }\end{array}$ & & & \\
\hline $\mathrm{m} 0$ & 0,54 & $2,78 b$ & $8,68 \mathrm{~b}$ & $14,58 b$ & $17,40 \mathrm{~b}$ & 0,70 & $1,92 \mathrm{~b}$ & $5,25 b$ & $7,77 \mathrm{~b}$ & & 2,42 & & & & & $3,08 c$ & $18,77 \mathrm{~b}$ & $2,15 b$ \\
\hline $\mathrm{m} 2$ & 0,69 & $0,82 a$ & 4,33a & $10,54 a$ & $13,97 a$ & 0,60 & $1,25 a$ & $3,25 a$ & $5,20 a$ & $6,42 a$ & 2,03 & 4,71 & $9,95 a$ & $17,28 a$ & $25,19 a$ & $1,33 a$ & $16,13 \mathrm{~b}$ & 1,82ab \\
\hline BNT $5 \%$ & - & 1,37 & 2,00 & 1,70 & 1,65 & - & 0,60 & 1,44 & 1,87 & 2,15 & - & - & 4,80 & 6,37 & 7,82 & 1,04 & 3,53 & 0,39 \\
\hline
\end{tabular}

Hasil sidik ragam menunjukkan bahwa penggunaan media tanam berpengaruh nyata pada variabel pertambahan tinggi tanaman dan jumlah batang (14 sampai 35 HSPT), pertambahan jumlah daun (21 sampai 35 HSPT), jumlah anakan, berat segar per tanaman, dan berat kering per tanaman.

Media tanam dalam hidroponik berfungsi sebagai media tempat tumbuhnya tanaman. Selain tempat tumbuh, media tanam juga berfungsi sebagai pendukung dalam menjalankan proses metabolisme. Unsur hara yang diserap oleh akar tanaman, sebagian unsur hara tersebut akan tersimpan di media tumbuhnya tanaman. Pada saat tanaman membutuhkan unsur hara kembali, unsur hara yang masih tertinggal pada media tanam bisa diserap akar dengan mudah.

Media tanam arang sekam memberikan pengaruh terbaik terhadap pertambahan tinggi dan jumlah batang tanaman seledri pada umur 14 HSPT (Tabel 2 dan Tabel 7). Arang sekam pada budidaya hidroponik sering digunakan sebagai media semai dan media tanam. Media arang sekam memiliki porositas yang baik, mudah mengikat air dan mampu menyimpan unsur hara, sehingga sangat cocok digunakan untuk pertumbuhan awal tanaman pada fase vegetatif. Selain itu, kandungan nitrogen pada arang sekam dapat memacu pertumbuhan tinggi dan perkembangan batang tanaman (Nurmayanti, 2008).

Umur tanaman 21 sampai 35 HSPT, media tanam rockwool mampu memberikan pertambahan tinggi dan jumlah batang tanaman terbaik dibandingkan dengan media tanam lainnya. Rockwool pula mampu memberikan pengaruh pertumbuhan dan hasil yang cukup tinggi terhadap pertambahan jumlah daun tanaman seledri pada umur 21 sampai 35 HSPT. Hal ini dikarenakan media rockwool memiliki daya serap air lebih besar daripada media arang sekam, yaitu sebesar $80 \%$. Rockwool pula merupakan media tanam yang paling umum dan sering digunakan sebagai media tanam pada sistem hidroponik (Nurmayanti, 2008).

Kombinasi media tanam arang sekam dan ampas teh pada budidaya hidroponik seledri memberikan pengaruh pertumbuhan tanaman yang rendah. Media yang terbuat dari pembakaran gabah padi memiliki daya serap yang sedang dan cepat menguap. Selain itu adanya kandungan tanin pada ampas teh dapat menghambat penyerapan unsur hara yang dibutuhkan tanaman (Sari, 2016).

Hasil sidik ragam penggunaan media tanam rockwool, arang sekam serta arang 
sekam dan ampas teh memberikan pengaruh yang nyata terhadap jumlah anakan seledri. Hal ini diduga karena rockwool mampu mengikat air dan larutan nutrisi hidroponik, sehingga unsur hara untuk tanaman selalu tersedia untuk proses pertumbuhan seledri (Sari, 2016). Media tanam arang sekam maupun kombinasi arang sekam dan ampas teh memberikan rata-rata jumlah anakan yang berpengaruh nyata. Media tanam arang sekam dan ampas teh memiliki unsur hara yang bermanfaat bagi pertumbuhan organ tanaman, khususnya pada anakan. Tetapi ketersediaan unsur hara belum dapat diserap oleh tanaman secara sempurna sehingga proses pembentukan anakan tanaman meenjadi rendah (Tripna, 2018).

Penggunaan media tanam rockwool, arang sekam serta kombinasi arang sekam dan ampas teh pada berat segar dan kering per tanaman berpengaruh sangat nyata. Hal ini dikarenakan adanya peningkatan tanaman dari pertambahan tinggi, jumlah batang dan jumlah daun tanaman. Selain itu ketersediaan unsur hara dari media tanam yang pada akhirnya diserap tanaman dapat memacu laju proses fotosintesis serta pertumbuhan tanaman. Grewal (1998) menyatakan bahwa salah satu faktor penting dalam menunjang pertumbuhan tanaman yaitu adanya unsur hara untuk tanaman karena peran unsur hara sebagai sumber energi dan pembentukan organ tanaman. Sehingga kandungan unsur hara yang sudah masuk pada sel-sel jaringan tanaman sangat mempengaruhi tinggi rendahnya berat segar suatu tanaman. Hasil dari berat segar dan berat kering per tanaman menunjukkan bahwa tanaman memiliki kemampuan yang baik dalam menyerap unsur hara. Berat segar berbanding lurus dengan berat kering per tanaman, yaitu apa bila berat segar per tanaman memiliki nilai yang tinggi, maka berat kering per tanaman pula akan menghasilkan nilai yang tinggi.

\section{Pengaruh Konsentrasi Larutan Nutrisi terhadap Pertumbuhan dan Hasil Tanaman Seledri (Apium graveolens L.)}

Tabel 3. Pengaruh Konsentrasi Larutan Nutrisi terhadap Pertumbuhan dan Hasil Tanaman seledri

\begin{tabular}{|c|c|c|c|c|c|c|c|c|c|c|c|c|c|c|c|c|c|c|}
\hline \multirow{2}{*}{$\begin{array}{c}\text { Konsentrasi } \\
\text { latutan } \\
\text { nutrisi (k) }\end{array}$} & \multicolumn{5}{|c|}{ Pertambahan tinggi tanaman $(\mathrm{cm})$} & \multicolumn{5}{|c|}{ Pertambahan jumlah batang (helai) } & \multicolumn{5}{|c|}{ Pertambahan jumlah daun (helai) } & \multirow{2}{*}{$\begin{array}{l}\text { J. anakan } \\
\text { (rumpun) }\end{array}$} & \multirow{2}{*}{$\begin{array}{l}\text { B. B. per } \\
\text { tanaman } \\
\text { (g) }\end{array}$} & \multirow{2}{*}{$\begin{array}{l}\text { B. K. per } \\
\text { tanaman } \\
\text { (g) }\end{array}$} \\
\hline & $\begin{array}{c}7 \\
\text { HSPT }\end{array}$ & $\begin{array}{c}14 \\
\text { HSPT }\end{array}$ & $\begin{array}{c}21 \\
\text { HSPT }\end{array}$ & $\begin{array}{c}28 \\
\text { HSPT }\end{array}$ & 35 HSPT & $\begin{array}{c}7 \\
\text { HSPT }\end{array}$ & $\begin{array}{c}14 \\
\text { HSPT }\end{array}$ & $\begin{array}{c}21 \\
\text { HSPT }\end{array}$ & $\begin{array}{c}28 \\
\text { HSPT }\end{array}$ & $\begin{array}{c}35 \\
\text { HSPT }\end{array}$ & $\begin{array}{c}7 \\
\text { HSPT }\end{array}$ & $\begin{array}{l}14 \\
\text { HSPT }\end{array}$ & $\begin{array}{l}21 \\
\text { HSPT }\end{array}$ & $\begin{array}{c}28 \\
\text { HSPT }\end{array}$ & $\begin{array}{c}35 \\
\text { HSPT }\end{array}$ & & & \\
\hline k1 & 0,42 & $0,94 a$ & $5,21 a$ & $9,13 a$ & $11,63 a$ & 0,67 & 1,48 & 3,18 & $4,39 a$ & $5,28 a$ & 2,44 & $4,96 a$ & 10,48 & $15,00 a$ & $21,89 a$ & $0,44 a$ & 10,88 & $1,44 a$ \\
\hline $\mathrm{k} 2$ & 0,69 & $2,57 \mathrm{~b}$ & $6,84 a b$ & $12,11 \mathrm{~b}$ & $14,80 \mathrm{~b}$ & 0,62 & 1,56 & 4,11 & $6,63 b$ & $7,93 b$ & 1,63 & $5,21 a$ & 11,89 & $20,41 \mathrm{ab}$ & $28,07 a b$ & $2,11 b$ & $15,76 \mathrm{~b}$ & $1,76 a$ \\
\hline k3 & 1,09 & $3,32 b$ & $8,72 \mathrm{~b}$ & $14,06 \mathrm{~b}$ & $18,09 \mathrm{c}$ & 0,63 & 2,26 & 5,15 & $7,56 \mathrm{~b}$ & $8,78 \mathrm{~b}$ & 2,33 & $8.07 \mathrm{~b}$ & 17,33 & $26,78 \mathrm{~b}$ & $35,37 \mathrm{~b}$ & $3,22 c$ & $20,55 c$ & $2,34 \mathrm{~b}$ \\
\hline k4 & 0,48 & $1,8 \mathrm{ab}$ & $6,6 \mathrm{ab}$ & $12,66 \mathrm{~b}$ & $15,09 \mathrm{~b}$ & 0,66 & 1,63 & 4,11 & $6,34 a b$ & $6,93 \mathrm{ab}$ & 2,29 & $5,30 a$ & 13,22 & $20,74 a b$ & $27,89 \mathrm{ab}$ & $2,44 \mathrm{c}$ & $15,82 b$ & $1,83 a$ \\
\hline BNT 5\% & - & 1,58 & 2,30 & 1,96 & 1,91 & - & - & - & 2,16 & 2,49 & - & 1,93 & - & 7,35 & 9,03 & 1,20 & 4,08 & 0,45 \\
\hline
\end{tabular}

Hasil sidik ragam penggunaan konsentrasi larutan nutrisi menunjukkan berpengaruh tidak nyata pada variabel pengamatan pertambahan tinggi tanaman 7 HSPT, jumlah batang 7, 14, dan 21 HSPT, dan jumlah daun 7 dan 21 HSPT. Konsentrasi larutan nutrisi tidak memberikan pengaruh yang berbeda nyata terhadap pertumbuhan tanaman, baik pada tinggi, jumlah batang maupun jumlah daun pada umur 7 HSPT. Tidak ada pengaruh dari larutan nutrisi dikarenakan akar dari bibit seledri yang baru dipindah tanam belum mampu menyerap larutan nutrisi yang tersedia di wadah penampung nutrisi. Pengamatan pada jumlah batang 14 dan 21 HSPT dan jumlah daun 21 HSPT menunjukkan bahwa larutan nutrisi belum memberikan respon pertumbuhan tanaman karena adanya faktor lingkungan, terutama suhu dan cahaya yang berubah-ubah. Suhu yang tidak menentu dapat mempengaruhi konsentrasi larutan nutrisi selain itu 
terjadinya pengendapan pada larutan nutrisi (Mas'ud, 2007).

Hasil sidik ragam perlakuan konsentrasi larutan nutrisi menunjukkan berpengaruh nyata pada pertambahan tinggi tanaman umur 14 sampai 35 HSPT, jumlah batang umur 28 dan 35 HSPT, jumlah daun umur 14, 28, dan 35 HSPT, jumlah anakan, berat segar dan berat kering per tanaman. Adanya respon pertumbuhan dari penggunaan konsentrasi larutan nutrisi karena perakaran yang sudah menempel pada kain flannel mampu menyerap unsur hara yang tersedia pada larutan nutrisi. Konsentrasi larutan nutrisi yang digunakan dalam budidaya hidroponik sangat berperan penting untuk tanaman karena digunakan sebagai sumber untuk mendapatkan makanan. Seluruh unsur hara yang tersedia pada nutrisi hidroponik merupakan unsur esensial yang sangat dibutuhkan dalam proses pertumbuhan dan perkembangan tanaman (Haryoto, 2009). Ditambahkan oleh Mas'ud (2007) bahwa setiap tanaman membutuhkan nutrisi yang berbeda-beda, pada umur yang berbeda nutrisi yang dibutuhkan pula berbeda. Nutrisi yang diberikan secara berlebihan menyebabkan keracunan pada tanaman, begitu pula sebaliknya, jika nutrisi yang diberikan kurang, maka pertumbuhan tanaman akan terhambat sehingga produksi yang dihasilkan kurang maksimal.

Hubungan antara konsentrasi larutan nutrisi dengan berat segar dan berat kering tanaman ditentukan dengan melakukan uji regresi polinomial ortogonal. Hasil uji ortogonal polinomial konsentrasi larutan terhadap berat segar tanaman diperoleh persamaan regresi $\hat{Y}=-1,1625+0,02794 X$ $0,0001 \mathrm{X}^{2}$, dengan koefisien korelasi $\mathrm{r}=$ 0,9512 (Gambar 1). Hal ini berarti pengaruh konsentrasi larutan nutrisi AB Mix terhadap hasil berat segar tanaman adalah sebesar 95\%. Nilai ini memberikan arti bahwa adanya hubungan yang erat dan searah antara konsentrasi larutan nutrisi dan berat segar tanaman. Jadi, berat segar tanaman sangat dipengaruhi oleh konsentrasi larutan nutrisi. Konsentrasi larutan nutrisi optimum yaitu 1.454,06 ppm dengan berat segar maksimum yaitu $19,16 \mathrm{~g}$.

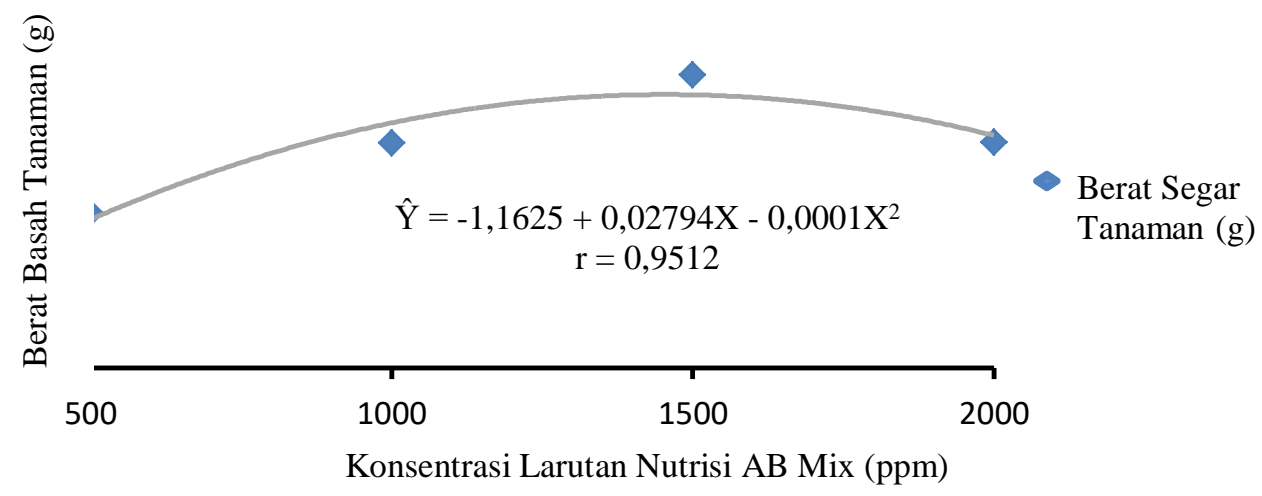

Gambar 1. Hubungan Konsentrasi Larutan Nutrisi AB Mix Terhadap Berat Segar Tanaman

Hasil uji ortogonal polinomial konsentrasi larutan terhadap berat kering tanaman diperoleh persamaan regresi $\hat{\mathrm{Y}}=$ $0,3675+0,0024 X-0,0000008 X^{2}$, dengan koefisien korelasi $\mathrm{r}=0,8839$ (Gambar 3). Hal ini berarti pengaruh konsentrasi larutan nutrisi $\mathrm{AB}$ Mix terhadap hasil berat kering tanaman adalah sebesar $88 \%$. Nilai ini memberikan arti bahwa adanya hubungan yang erat dan searah antara konsentrasi larutan nutrisi dan berat kering tanaman. Jadi, berat kering tanaman sangat dipengaruhi oleh konsentrasi larutan nutrisi. Konsentrasi larutan nutrisi AB Mix optimum yaitu $1.460,84 \mathrm{ppm}$ dengan berat kering maksimum yaitu $2,14 \mathrm{~g}$. 


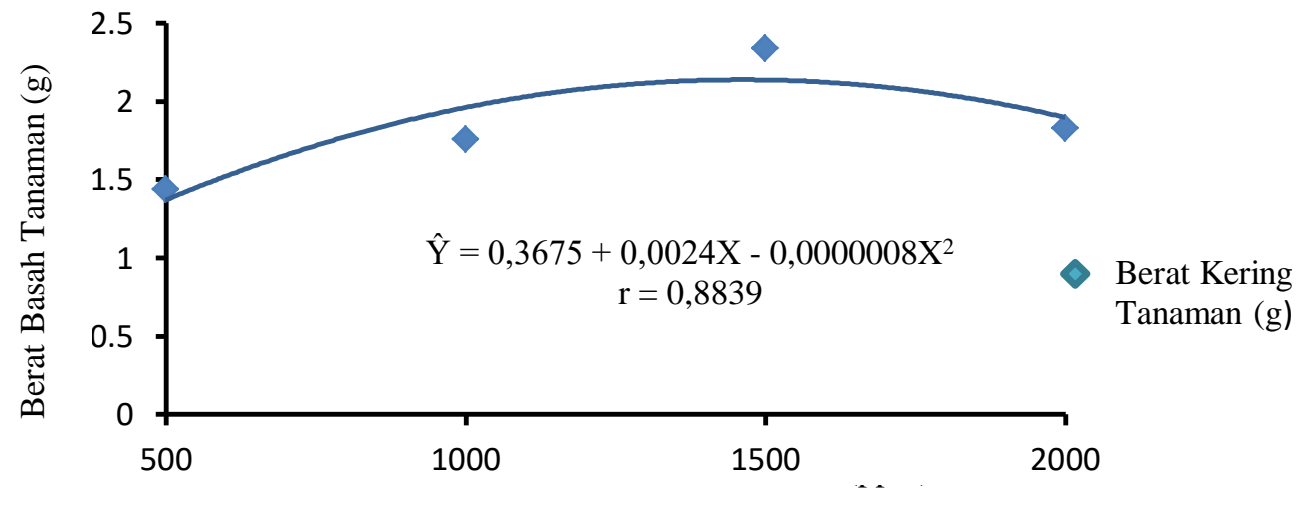

Konsentrasi Larutan Nutrisi AB Mix (ppm)

Gambar 2. Hubungan Konsentrasi Larutan Nutrisi AB Mix terhadap Berat Kering Tanaman

Hasil penelitian dengan berbagai konsentrasi larutan $\mathrm{AB}$ Mix, secara keseluruhan didapatkan konsentrasi 500, 1.000 dan 2.000 ppm memberikan pertumbuhan tanaman seledri rendah. Hal ini diduga karena pada konsentrasi 500 dan 1.000 ppm tanaman mengalami kekurangan unsur hara dalam proses pertumbuhannya. Tanaman yang mengalami kekurangan unsur hara maka pertumbuhan akan terhambat dan produksinya menurun (Grewal, 1998. Sedangkan pada konsentrasi 2.000 ppm tanaman mengalami kelebihan unsur hara, yang biasa disebut keracunan atau toksik (Mas'ud, 2007). Keracunan mengakibatkan laju pertumbuhan tanaman akan menurun disertai penurunan pada berat kering tanaman. Hal ini dikarenakan penggunaan konsentrasi yang lebih tinggi hanya meningkatkan kandungan unsur hara, tetapi tidak meningkatkan hasil pada tanaman (Haryoto, 2009). Setiap tanaman memiliki kebutuhan unsur hara berbeda-beda untuk proses pertumbuhannya dan tergantung dari setiap jenis tanamannya (Grewal, 1998). Nutrisi yang diberikan untuk tanaman harus sesuai dengan kebutuhan, karena bila tanaman mengalami kekurangan ataupun kelebihan unsur hara maka pertumbuhan tanaman itu sendiri akan terganggu. Dinyatakan oleh Mas;ud (2007) bahwa nutrisi yang diberikan sesuai dengan kebutuhan tanaman akan memberikan pertumbuhan yang baik dan meningkatkan morfogenesis pada tanaman. Hasil uji ortogonal polinomial hubungan konsentrasi larutan nutrisi dengan berat kering tanaman diperoleh regresi kuadratik dan tercapai titik optimum 1.460,84 ppm dengan hasil berat kering tanaman seledri maksimum 2,14 g.

\section{KESIMPULAN}

Berdasarkan hasil penelitian dan pembahasan dapat diambil kesimpulan yaitu sebagai berikut :

1. Ada interaksi antara media tanam dan konsentrasi larutan nutrisi pada pertumbuhan dan hasil tanaman seledri. Interaksi antara media tanam arang sekam + ampas teh dengan konsentrasi 1.500 ppm $\left(\mathrm{m}_{2} \mathrm{k}_{3}\right)$ memberikan pengaruh terbaik terhadap pertumbuhan dan hasil tanaman seledri.

2. Perlakuan media tanam berpengaruh nyata pada pertumbuhan dan hasil tanaman seledri. Media tanam arang sekam memberikan pengaruh terbaik terhadap pertumbuhan dan hasil tanaman seledri.

3. Perlakuan konsentrasi larutan nutrisi $A B$ Mix berpengaruh nyata terhadap pertumbuhan dan hasil tanaman seledri. Uji ortogonal polinomial hubungan konsentrasi larutan nutrisi dengan berat kering tanaman diperoleh regresi 
kuadratik dan tercapai konsentrasi larutan nutrisi $\mathrm{AB}$ Mix optimum 1.460,84 ppm dengan hasil berat kering tanaman seledri maksimum 2,14 g.

\section{DAFTAR PUSTAKA}

Grewal. 1998. Propagation of ornamental Plants. New Delhi: Kalyani Publisher.

Haryoto, A. 2009. Bertanam Seledri Secara Hidroponik. Kanisius, Yogyakarta.

Kementrian Kesehatan Republik Indonesia. 2017. Hari Gizi Nasional 2017, Ayo Makan Sayur dan Buah Setiap Hari. www.kemkes.go.id. Diakses 13 September 2020.

Mas'ud, H. 2007. Sistem Hidroponik dengan Nutrisi dan Media Tanam berbeda Terhadap Pertumbuhan dan Hasil Selada. Jurnal Media Litbang Sulteng 2(2): 131-136.

Nurmayanti, T. R. 2008. Efektifitas Air Kelompokapa dan Ampas Teh Terhadap Pertumbuhan Tanaman Sri Rejeki (Aglonema donna carmen) pada Media Tanam yang Berbeda. Surakarta.

Perwitasari. 2012. Pengaruh media tanam dan nutrisi terhadap pertumbuhan tanaman pakchoi dengan sistem hidroponik. Jurnal Agrovigor. Vol 1(5): 14-19
Rahayu, A. 2014. Pengaruh macam media dan konsentrasi pupuk fermentasi ampas tahu terhadap pertumbuhan dan hasil tanaman seledri (Apium graveolens 1.) secara hidroponik. Jurnal Ilmiah Ilmu Tanah dan Agroklimatologi. 5(11): 75-82.

Sari, R. 2016. Pengaruh media tanam pada berbagai konsentrasi nutrisi terhadap pertumbuhan dan hasil seledri dengan sistem tanam hidroponik NFT. Jurnal Daun. 3 (1) : 12-17

Steel, R.G.D. dan Torrie, J.H. 1989. Prinsip dan Prosedur Statistik. Terjemahan Bambang Sumantri. Gramedia Pustaka. Jakarta.

Sudarsono, E. 2014. Pemanfaatan Limbah Teh, Sekam Padi dan Arang Sekam sebagai Media Tumbuh Bibit Trembesi (Samanea saman). Jurnal Sylva Lestari. Vol 2 (2) : 61-70.

Sunarjono. 2003. Bertanam Seledri. Kanisius. Yogyakarta.

Tripana, B. 2018. Respon konsentrasi nutrisi hidroponik terhadap tiga jenis tanaman sawi (Brassica juncea L). Jurnal Agritrop. Vol 16 (2) : 237249. 